[RAdiocarbon, Vol 26, No. 2, 1984, P 196-205]

\title{
HAMBURG UNIVERSITY RADIOCARBON DATES III
}

\author{
H W SCHARPENSEEL, HEINRICH SCHIFFMANN, \\ and BERND HINTZE \\ Ordinariat für Bodenkunde der Universität Hamburg \\ Allendeplatz 2, 2000 Hamburg 13, West Germany
}

The following list consists of dates of soil samples, partly produced in the former Bonn laboratory and bearing the code designations, BONN, and partly in the present dating lab at Hamburg University. The list comprises Mollisols and Inceptisols from Germany, sampled by layer and dated as whole soil, hydrolysis residue, and hydrolysate. Other profiles represent selected Australian Vertisols and Krasnozems, sampled by layer as well. Dates derived from marshes of the Elbe River as well as from paleosols buried by coastal levees are also included in the list. Pretreatment of soil samples is described in Scharpenseel and Pietig (1969) and Scharpenseel (1972; 1977).

ACKNOWLEIGMENT

This work was supported by the Deutsche Forschungsgemeinschaft.

\section{Germany}

Soil profile dating was done on $5 \mathrm{~cm}$ layers of Hapludoll in Würmian loess, near town of Söllingen, $\mathrm{S}$ of Brunswick $\left(52^{\circ} 5^{\prime} \mathrm{N}, 10^{\circ} 59^{\prime} \mathrm{E}\right)$. First profile is highly organic and near surface. As much as possible, dates derived from original soil after removal of carbonate $\mathrm{C}$ were compared with dates of $6 \mathrm{~N} \mathrm{HCl} \mathrm{hydrolysate,} \mathrm{of} \mathrm{hydrolysis} \mathrm{residue,} \mathrm{and} \mathrm{of} \mathrm{acid} \mathrm{phase} \mathrm{used}$ for carbonate destruction. Results, with other data sets, will contribute to integrated soil organic matter decomposition model, comprising initial phase of exponential decomposition of uniformly labeled plant material as well as steady-state slowed phase based on natural ${ }^{14} \mathrm{C}$ measurements (Scharpenseel \& Neue, in press). Tables 1 and 2 show our results.

Samples coll and subm 1976 by $\mathrm{H}$ W Scharpenseel and H Schiffmann. Histic Hapludoll (BONN-2225 to -2272) shows expected increased age with depth, but with inflection below $70 \mathrm{~cm}$. Observed repeatedly, this could reflect earthworm transport of young, nearsurface organics, deep into soil when worms descend for hibernation. As demonstrated, HAM623 to -801 ( R, v 19, p 177), first $6 \mathrm{~N} \mathrm{HCl} \mathrm{hydrolysis} \mathrm{residue} \mathrm{is} \mathrm{not} \mathrm{much}$ older than original carbonate-free soil. Hydrolysate, itself, lags behind apparent age of residue. All samples based on acid from carbonate destruction are very small. Ages obtained are erratic and represent mixtures of atmospheric and dissolved carbonate-C species.

Typic Hapludoll (BONN-2275 to -2289) reveals generally younger dates. We discovered after sampling, that area was covered temporarily by sugar beet earth silo. Leachates produced rejuvenation. Again, there was age inflection below $65 \mathrm{~cm}$, possibly due to earthworm transport. Hydrolysate residues are markedly older; hydrolysate itself on bomb carbon level. Obviously, acid hydrolysis could remove part but not all leached, rejuvenating $C$. Dates produced from $\mathrm{C}$ in acid from carbonate 
HW Scharpenseel, Heinrich Schiffmann, and Bernd Hintze
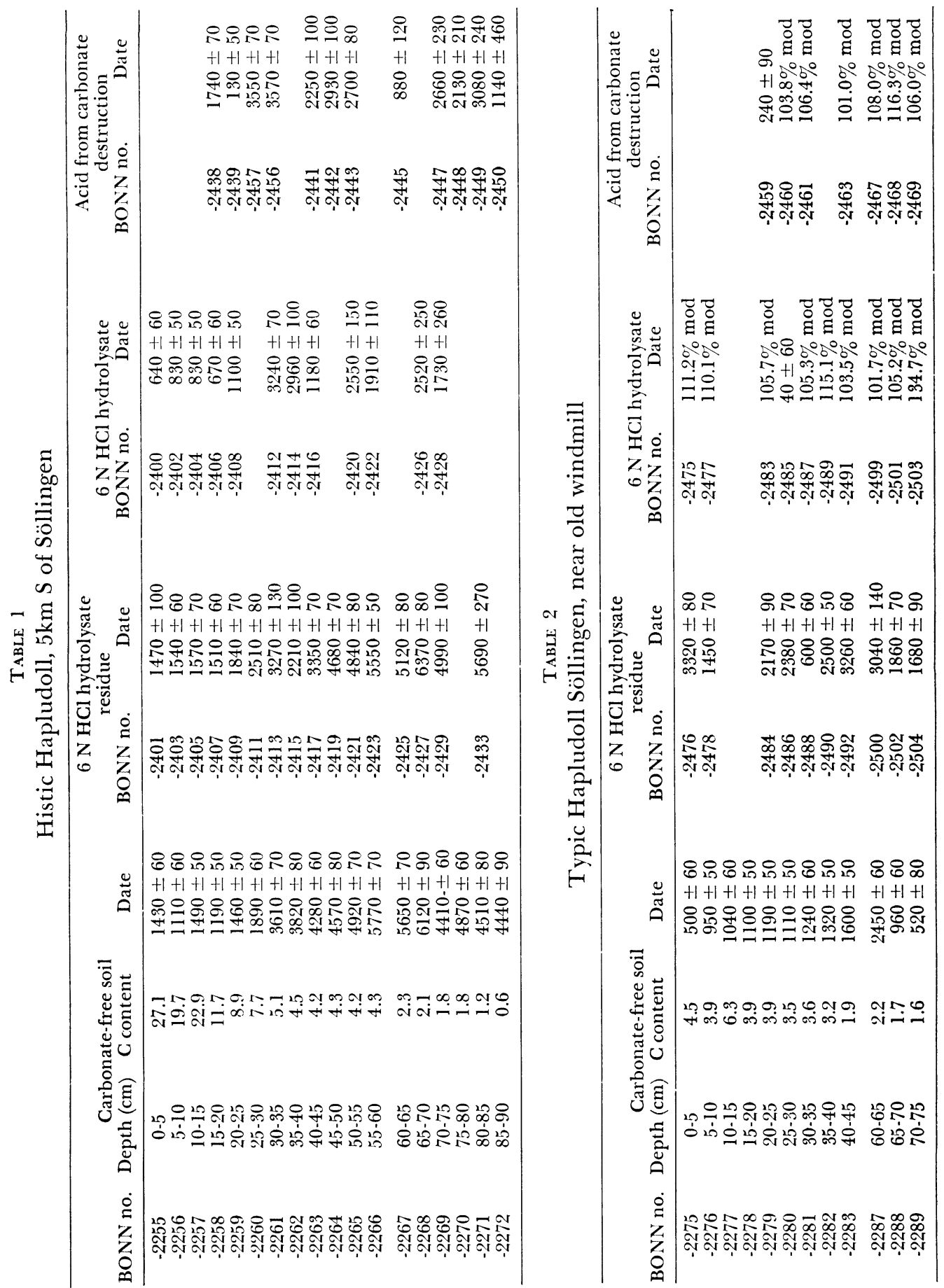
destruction were all modern and consisted predominantly of atmospheric young carbon, bomb carbon levels being reduced by intermixture with small dissolved quantities of old carbonate $\mathrm{C}$.

Five-cm layers from Eutrochrept profile near Hohentrüdingen in Jurassic (Dogger), loam and Haplaquept, on Isar terrace, loess, near Landshut/Ergolding.

Hohentrüdingen, Nördlinger Ries crater $\left(49^{\circ} 0^{\prime} \mathrm{N}, 10^{\circ} 42^{\prime} \mathrm{E}\right)$.

$\begin{array}{llr}\text { HAM-635. } & 5 \text { to } 10 \mathrm{~cm} & 102.6 \pm 0.5 \% \text { modern } \\ \text { HAM-636. } & 10 \text { to } 15 \mathrm{~cm} & 200 \pm 90 \\ \text { HAM-637. } & 15 \text { to } 20 \mathrm{~cm} & 102.9 \pm 0.4 \% \text { modern } \\ \text { HAM-638. } & 20 \text { to } 25 \mathrm{~cm} & 860 \pm 70 \\ \text { HAM-639. } & 25 \text { to } 30 \mathrm{~cm} & 2110 \pm 80 \\ \text { HAM-640. } & 30 \text { to } 35 \mathrm{~cm} & 2700 \pm 90 \\ \text { HAM-641. } & 35 \text { to } 40 \mathrm{~cm} & 3020 \pm 80 \\ \text { HAM-642. } & 40 \text { to } 45 \mathrm{~cm} & 4170 \pm 90 \\ \text { HAM-643. } & 45 \text { to } 50 \mathrm{~cm} & 5160 \pm 90 \\ \text { HAM-644. } & 50 \text { to } 55 \mathrm{~cm} & 3880 \pm 70 \\ \text { HAM-645. } & 55 \text { to } 60 \mathrm{~cm} & 3550 \pm 90 \\ \text { HAM-646. } & 60 \text { to } 65 \mathrm{~cm} & 6700 \pm 80 \\ \text { HAM-647. } & 65 \text { to } 70 \mathrm{~cm} & 8500 \pm 130 \\ \text { HAM-648. } & 70 \text { to } 75 \mathrm{~cm} & 10,920 \pm 140 \\ \text { HAM-649. } & 75 \text { to } 80 \mathrm{~cm} & 10,980 \pm 140 \\ \text { HAM-650. } & 80 \text { to } 85 \mathrm{~cm} & 13,750 \pm 190 \\ \text { HAM-651. } & 85 \text { to } 90 \mathrm{~cm} & 13,250 \pm 180 \\ \text { HAM-652. } & 90 \text { to } 95 \mathrm{~cm} & 13,440 \pm 180 \\ \text { HAM-653. } & 95 \text { to } 100 \mathrm{~cm} & 16,770 \pm 280 \\ \text { HAM-654. } & 100 \text { to } 105 \mathrm{~cm} & \\ \text { HAmD } & & \end{array}$

Samples coll and subm 1976 by H Schiffmann and B Hofmann, Bayrisches Geol Landesamt, München. Explorative samples of same area are HAM-47 to -49 (R, v 18, p 272). Age inflection of HAM-645 and -646 could be due to slightly vertic properties of soil by migration through cracks. Dates will be used for decomposition model.

Landshut/Ergolding, loess, lowest Isar terrace $\left(48^{\circ} 35^{\prime} \mathrm{N}, 12^{\circ} 11^{\prime} \mathrm{E}\right)$.
HAM-655. 0 to $5 \mathrm{~cm}$
$110.0 \pm 0.6 \%$ modern 
HAM-656. 5 to $10 \mathrm{~cm}$

HAM-657. 10 to $15 \mathrm{~cm}$

HAM-658. 15 to $20 \mathrm{~cm}$

HAM-659. 20 to $25 \mathrm{~cm}$

HAM-660. 25 to $30 \mathrm{~cm}$

HAM-661. 30 to $35 \mathrm{~cm}$

HAM-662. 35 to $40 \mathrm{~cm}$

HAM-663. 40 to $45 \mathrm{~cm}$

HAM-664. 45 to $50 \mathrm{~cm}$

HAM- $665 . \quad 50$ to $55 \mathrm{~cm}$

HAM-666. 55 to $60 \mathrm{~cm}$

HAM-667. 60 to $65 \mathrm{~cm}$

HAM-668. 65 to $70 \mathrm{~cm}$

HAM-669. 70 to $75 \mathrm{~cm}$

HAM-670. 75 to $80 \mathrm{~cm}$

HAM-671. 80 to $85 \mathrm{~cm}$

HAM-672. 85 to $90 \mathrm{~cm}$

$$
\begin{aligned}
& 105.2 \pm 0.8 \% \text { modern } \\
& 105.6 \pm 0.7 \% \text { modern } \\
& 108.7 \pm 0.9 \% \text { modern }
\end{aligned}
$$$$
720 \pm 100
$$$$
180 \pm 70
$$$$
2170 \pm 80
$$$$
3440 \pm 80
$$$$
4210 \pm 90
$$$$
3810 \pm 90
$$$$
4990 \pm 80
$$$$
4980 \pm 90
$$$$
5550 \pm 80
$$$$
4970 \pm 90
$$$$
5560 \pm 80
$$$$
3990 \pm 90
$$$$
2930 \pm 80
$$$$
3090 \pm 70
$$

Samples coll and subm 1976 by $\mathrm{H}$ Schiffmann and B Hofmann, Bayrisches Geol Landesamt, München. Age inflection of HAM-670 to -672 not easy to explain, but same trend was observed in other profiles, perhaps result of animal transport. Age $v s$ depth series of dates to be used for decomposition model.

Humic matter in coastline levee along Eastern Sea coast near Heiligenhafen $\left(54^{\circ} 29^{\prime} \mathrm{N}, 10^{\circ} 55^{\prime} \mathrm{E}\right)$.

$\begin{array}{llr}\text { BONN-2367. } & \text { Cliff wall, sampling spot } G 75 / 2,16 \text { to } 26 \mathrm{~cm} & 300 \pm 60 \\ \text { BONN-2368. } & 37 \text { to } 47 \mathrm{~cm} & 460 \pm 60 \\ \text { BONN-2370. } & 55 \text { to } 65 \mathrm{~cm} & 880 \pm 80 \\ \text { BONN-2372. } & \text { Sampling spot } \mathrm{G} 75 / 3,20 \text { to } 30 \mathrm{~cm} & 360 \pm 70 \\ \text { BONN-2373. } & 40 \text { to } 50 \mathrm{~cm} & 870 \pm 70 \\ \text { BONN-2375. } & 98 \text { to } 110 \mathrm{~cm} & 2300 \pm 70 \\ \text { BONN-2376. } & 110 \text { to } 120 \mathrm{~cm} & 1760 \pm 70 \\ \text { BONN-2377. } & 130 \text { to } 140 \mathrm{~cm} & 1780 \pm 100 \\ \text { BONN-2378. } & \text { Sampling spot G } 75 / 4,10 \text { to } 20 \mathrm{~cm} & 210 \pm 70\end{array}$


BONN-2379. 105 to $115 \mathrm{~cm}$

$$
200 \pm 70
$$

BONN-2380. 150 to $160 \mathrm{~cm}$

$1090 \pm 120$

BONN-2381. 175 to $185 \mathrm{~cm}$

$1180 \pm 70$

BONN-2382. Sampling spot G $75 / 5,120$ to $130 \mathrm{~cm}$

$1440 \pm 80$

BONN-2383. 130 to $140 \mathrm{~cm}$

$2440 \pm 70$

BONN-2384. 140 to $155 \mathrm{~cm}$

$2970 \pm 80$

BONN-2385. 158 to $165 \mathrm{~cm}$

$6240 \pm 110$

Samples coll and subm 1975 by D Goetz, Ordin Bodenkunde, Univ Hamburg. Comment: results are supplemental to dates HAM-123 to -127 ( $\mathrm{R}, \mathrm{v}$ 18, p 279), helping date beach wall formation. Most $\mathrm{C}$ relics rather young, Sub-atlantic/Sub-boreal, except BONN-2385, reflecting origin in period of climatic optimum. burg.

Elbe River marsh series, Allermöhe, Vier- und Marschlande, S Ham-

HAM-826. Allermöhe, Pastoratsweg, field plot near

$2670 \pm 80$ cemetery $\left(53^{\circ} 28^{\prime} \mathrm{N}, 10^{\circ} 7^{\prime} \mathrm{E}\right)$ peat, 80 to $90 \mathrm{~cm}$.

HAM-827. 90 to $100 \mathrm{~cm}$

$2090 \pm 80$

HAM-828. Allermöhe, cemetery between church and

$2220 \pm 70$ dike $\left(53^{\circ} 28^{\prime} \mathrm{N}, 10^{\circ} 7^{\prime} \mathrm{E}\right) 430$ to $440 \mathrm{~cm}$.

HAM-829. Peat, 440 to $450 \mathrm{~cm}$

$2370 \pm 80$

HAM-830. Peat, 450 to $460 \mathrm{~cm}$

$2640 \pm 70$

HAM-831. Allermöhe, church, below tower, old warft

$2040 \pm 70$ (settlement), peat $\left(52^{\circ} 28^{\prime} \mathrm{N}, 10^{\circ} 7^{\prime} \mathrm{E}\right), 340$ to $360 \mathrm{~cm}$.

HAM-832. Peat, 360 to $380 \mathrm{~cm}$

$1470 \pm 70$

HAM-833. Peat, 380 to $400 \mathrm{~cm}$

$2270 \pm 80$

HAM-834. Allermöhe, marsh, super-hwy line, peat $\left(58^{\circ} 28^{\prime} \mathrm{N}, 10^{\circ} 9^{\prime} \mathrm{E}\right), 160$ to $180 \mathrm{~cm}$.

HAM-835. Fossil A-horizon, 210 to $215 \mathrm{~cm}$

$1440 \pm 70$

HAM-836. Allermöhe, church, buried fossil soil (A-horizon) $\left(53^{\circ} 28^{\prime} \mathrm{N}, 10^{\circ} 7^{\prime} \mathrm{E}\right), 290$ to $310 \mathrm{~cm}$.

HAM-837. Allermöhe, cemetery (old part), fossil A-horizon $\left(53^{\circ} 28^{\prime} \mathrm{N}, 10^{\circ} 7^{\prime} \mathrm{E}\right), 275$ to $295 \mathrm{~cm}$.

HAM-838. Humic clay, 355 to $375 \mathrm{~cm}$

$7420 \pm 110$

$1560 \pm 70$

$3970 \pm 80$

HAM-839. Peat, 375 to $390 \mathrm{~cm}$

$2110 \pm 70$

$3240 \pm 70$ 
HAM-840. Basal peat, 420 to $430 \mathrm{~cm}$

HAM-841. Allermöhe, cemetery (new part), peat, $\left(53^{\circ} 28^{\prime} \mathrm{N}, 10^{\circ} 7^{\prime} \mathrm{E}\right), 245$ to $255 \mathrm{~cm}$.

Samples coll and subm 1976 by B Hintze. Comment: dated peats belong stratigraphically to same phase as samples, HAM-794 to $-799(\mathrm{R}, \mathrm{v} 19$, p 179), Sub-boreal and early Sub-atlantic: divergent ages signify soil surfaces of different dates of origin (church and cemetery warft). They also relate to differing growth periods of peat layers and different grades of their compaction. Fossil Ah horizon of HAM-835 probably represents formation of Boreal soil at surface of early Holocene sands.

Peat samples underlying valley of Elbe River, sampled in three crosssections $\mathrm{E}$ and $\mathrm{W}$ of Hamburg.

HAM-1393. Hamburg-Allermöhe, peat, $\left(53^{\circ} 31^{\prime} \mathrm{N}, \quad 3560 \pm 70\right.$ $\left.10^{\circ} 6^{\prime} \mathrm{E}\right), 80$ to $90 \mathrm{~cm}$.

HAM-1394. Hamburg-Moorfleet, peat, $\left(53^{\circ} 30^{\prime} \mathrm{N}, \quad 3810 \pm 80\right.$ $\left.20^{\circ} 6^{\prime} \mathrm{E}\right), 140$ to $150 \mathrm{~cm}$.

HAM-1395. Peat, 130 to $140 \mathrm{~cm}$

$$
3850 \pm 80
$$

HAM-1396. Peat, 110 to $120 \mathrm{~cm}$

$3060 \pm 80$

HAM-1397. Peat, 170 to $180 \mathrm{~cm}$

$2790 \pm 80$

HAM-1398. Hamburg-Moorfleet, peat $\left(53^{\circ} 30^{\prime} \mathrm{N}\right.$,

$2220 \pm 80$ $\left.10^{\circ} 6^{\prime} \mathrm{E}\right), 160$ to $170 \mathrm{~cm}$.

HAM-1399. Altes Land/Agathenburg, peat $\left(53^{\circ} 35^{\prime} \quad 4770 \pm 80\right.$ $\left.\mathrm{N}, 9^{\circ} 33^{\prime} \mathrm{E}\right), 500$ to $510 \mathrm{~cm}$.

HAM-1400. Altes Land/Agathenburg, peat $\left(53^{\circ} 34^{\prime} \quad 4590 \pm 80\right.$ $\left.\mathrm{N}, 9^{\circ} 32^{\prime} \mathrm{E}\right), 310$ to $320 \mathrm{~cm}$.

HAM-1401. Peat, 320 to $330 \mathrm{~cm}$

$$
5320 \pm 90
$$

HAM-1402. Altes Land/Agathenburg, peat $\left(53^{\circ} 35.5^{\prime} \quad 4970 \pm 80\right.$ $\left.\mathrm{N}, 9^{\circ} 34^{\prime} \mathrm{E}\right), 540$ to $550 \mathrm{~cm}$.

HAM-1403. Haseldorfer Marsch, peat $\left(53^{\circ} 38^{\prime} \mathrm{N}, \quad 4980 \pm 80\right.$ $\left.9^{\circ} 37.5^{\prime} \mathrm{E}\right), 620$ to $630 \mathrm{~cm}$.

HAM-1404. Hamburg-Neuland, basal peat $\left(53^{\circ} 27^{\prime} \quad 8140 \pm 100\right.$ $\left.\mathrm{N}, 10^{\circ} 1.5^{\prime} \mathrm{E}\right), 260$ to $270 \mathrm{~cm}$.

HAM-1405. Hamburg-Spadenland, peat $\left(53^{\circ} 29^{\prime} \mathrm{N}, \quad 3400 \pm 70\right.$ $\left.10^{\circ} 3.5^{\prime} \mathrm{E}\right), 190$ to $200 \mathrm{~cm}$.

HAM-1406. Altes Land/Agathenburg, peat $\left(53^{\circ} 34^{\prime} \quad 4700 \pm 90\right.$ $\mathrm{N}, 9^{\circ} 32^{\prime} \mathrm{E}$ ), 360 to $370 \mathrm{~cm}$.

Samples coll and subm 1977 by B Hintze. Comment: two growth phases of peat can be distinguished in Elbe valley, dist Hamburg, older 
one between 5000 and $4500 \mathrm{BP}$, which is limited to Altes Land and Haseldorfer Marsch regions; younger one between 4200 and $3000 \mathrm{BP}$ in region of Vier and Marschlande.

${ }^{14} \mathrm{C}$ age at base of peat layer, which reaches depth up to $6 \mathrm{~m}$, eg, in Hamburg Neuland (HAM-1404), proves that peat began to form in this area during Boreal. Date also indicates that Elbe $\mathrm{R}$ did not reach this area before younger, Sub-atlantic period, since peat growth was nowhere interrupted by sedimentation phase.

\section{Australia}

Two typic Australian Vertisol and Oxisol (Krasnozem) profiles were dated by layers. Investigations of natural ${ }^{14} \mathrm{C}$ scanning of Australian Vertisols and Krasnozems are continuing (see BONN-664 to -772 ; R, v 15, p 258-263) for testing C dynamics of these soils.

Vertisol (Chromustert) on gently undulating plain at $+300 \mathrm{~m}$, in Chinchilla, $80 \mathrm{~m}$ from profile 10c(B554) (Handbook of Australian Soils, 1968, p 88-90). Deeply weathered profile on Mesozoic sandstone, covered with Acacia harpophylla $\left(26^{\circ} 43^{\prime} \mathrm{S}, 150^{\circ} 36^{\prime} \mathrm{E}\right)$.

$\begin{array}{llr}\text { HAM-674. } & 2.58 \% \text { C, } 0 \text { to } 10 \mathrm{~cm} & 100 \pm 70 \\ \text { HAM-675. } & 1.48 \% \text { C, } 10 \text { to } 20 \mathrm{~cm} & 110 \pm 70 \\ \text { HAM-676. } & 1.01 \% \text { C, } 20 \text { to } 30 \mathrm{~cm} & 120 \pm 70 \\ \text { HAM-677. } & 0.65 \% \text { C, } 30 \text { to } 40 \mathrm{~cm} & 660 \pm 80 \\ \text { HAM-678. } & 0.59 \% \text { C, } 40 \text { to } 50 \mathrm{~cm} & 1200 \pm 80 \\ \text { HAM-679. } & 0.53 \% \text { C, } 50 \text { to } 60 \mathrm{~cm} & 1350 \pm 80 \\ \text { HAM-680. } & 0.48 \% \text { C, } 60 \text { to } 70 \mathrm{~cm} & 2430 \pm 80 \\ \text { HAM-681. } & 0.42 \% \mathrm{C}, 70 \text { to } 80 \mathrm{~cm} & 2500 \pm 80 \\ \text { HAM-682. } & 0.43 \% \text { C, } 80 \text { to } 90 \mathrm{~cm} & 2280 \pm 100 \\ \text { HAM-684. } & 0.37 \% \text { C, } 100 \text { to } 110 \mathrm{~cm} & 1090 \pm 100 \\ \text { HAM-685. } & 0.35 \% \text { C, } 110 \text { to } 120 \mathrm{~cm} & 2760 \pm 90 \\ \text { HAM-686. } & 0.33 \% \text { C, } 120 \text { to } 130 \mathrm{~cm} & 2730 \pm 70 \\ \text { HAM-687. } & 0.30 \% \text { C, } 130 \text { to } 140 \mathrm{~cm} & 4550 \pm 60 \\ \text { HAM-690. } & 0.24 \% \text { C, } 160 \text { to } 170 \mathrm{~cm} & 4670 \pm 90 \\ \text { HAM-692. } & 0.22 \% \text { C, } 180 \text { to } 190 \mathrm{~cm} & 6470 \pm 100 \\ \text { HAM-694. } & 0.18 \% \text { C, } 200 \text { to } 210 \mathrm{~cm} & 6510 \pm 100 \\ \text { HAM-696. } & 0.15 \% \text { C, } 220 \text { to } 230 \mathrm{~cm} & 7850 \pm 110 \\ \text { HAM-697. } & 0.15 \% \text { C, } 230 \text { to } 240 \mathrm{~cm} & 7700 \pm 140 \\ \text { HAM-698. } & 0.13 \% \text { C, } 240 \text { to } 250 \mathrm{~cm} & 8190 \pm 270\end{array}$


HAM-699. $0.12 \% \mathrm{C}, 250$ to $260 \mathrm{~cm}$

HAM-700. $0.12 \% \mathrm{C}, 260$ to $270 \mathrm{~cm}$

$9690 \pm 150$

HAM-701. $0.13 \%$ C, 270 to $280 \mathrm{~cm}$

$9340 \pm 140$

HAM-702. $0.14 \% \mathrm{C}, 280$ to $290 \mathrm{~cm}$

$9850 \pm 170$

Vertisol (Chromustert) on lower edge of gently sloping pediment in Paget. Deeply weathered profile on lower Cretaceous sand and mudstone $\left(27^{\circ} 27^{\prime} \mathrm{S}, 150^{\circ} 31^{\prime} \mathrm{E}\right)$.

HAM-734. $1.96 \% \mathrm{C}, 10$ to $20 \mathrm{~cm}$

$$
102 \pm 20
$$

HAM-735. $1.47 \%$ C, 20 to $30 \mathrm{~cm}$

HAM-736. $1.29 \% \mathrm{C}, 30$ to $40 \mathrm{~cm}$

$1360 \pm 90$

HAM-737. $1.10 \% \mathrm{C}, 40$ to $50 \mathrm{~cm}$

$1760 \pm 80$

HAM-739. $0.96 \% \mathrm{C}, 60$ to $70 \mathrm{~cm}$

$2290 \pm 80$

HAM-740. $0.94 \% \mathrm{C}, 70$ to $80 \mathrm{~cm}$

$2780 \pm 70$

HAM-741. $0.86 \% \mathrm{C}, 80$ to $90 \mathrm{~cm}$

$2870 \pm 70$

HAM-742. $0.85 \%$ C, 90 to $100 \mathrm{~cm}$

$3250 \pm 80$

HAM-743. $0.77 \% \mathrm{C}, 100$ to $110 \mathrm{~cm}$

$3270 \pm 80$

HAM-744. $0.66 \% \mathrm{C}, 110$ to $120 \mathrm{~cm}$

$3360 \pm 90$

HAM-745. $0.72 \%$ C, 120 to $130 \mathrm{~cm}$

$5560 \pm 80$

HAM-746. $0.66 \%$ C, 130 to $140 \mathrm{~cm}$

$5170 \pm 100$

HAM-747. $0.50 \% \mathrm{C}, 140$ to $150 \mathrm{~cm}$

$6540 \pm 150$

HAM-748. $0.51 \% \mathrm{C}, 150$ to $160 \mathrm{~cm}$

$7790 \pm 110$

HAM-749. $0.49 \% \mathrm{C}, 160$ to $170 \mathrm{~cm}$

$8840 \pm 120$

HAM-750. $0.50 \% \mathrm{C}, 170$ to $180 \mathrm{~cm}$

$8220 \pm 130$

HAM-751. $0.48 \% \mathrm{C}, 180$ to $190 \mathrm{~cm}$

$10,550 \pm 130$

HAM-755. $0.42 \% \mathrm{C}, 220$ to $230 \mathrm{~cm}$

$10,670 \pm 100$

HAM-758. $0.36 \%$ C, 250 to $260 \mathrm{~cm}$

$11,570 \pm 210$

$10,890 \pm 130$

HAM-759 to -762 . 260 to $300 \mathrm{~cm}$

C content too low for reliable dates.

Eutrustox (Krasnozem) on plateau remnant above precipitous scarp in clay laterite, in Gabbinbar. Soil formation from early Tertiary basalt with strongly weathered saprolitic transition zone $\left(27^{\circ} 26^{\prime} \mathrm{S}, 159^{\circ} 59^{\prime} \mathrm{E}\right)$.

HAM-719. $11.25 \% \mathrm{C}, 0$ to $8 \mathrm{~cm}$

$117.7 \pm 0.9 \%$ modern

HAM-720. $4.50 \% \mathrm{C}, 8$ to $20 \mathrm{~cm}$

$110.4 \pm 0.9$ 
$\begin{array}{llr}\text { HAM-722. } & 1.71 \% \mathrm{C}, 34 \text { to } 47 \mathrm{~cm} & 30 \pm 70 \\ \text { HAM-723. } & 1.09 \% \mathrm{C}, 47 \text { to } 60 \mathrm{~cm} & 370 \pm 70 \\ \text { HAM-724. } & 0.91 \% \mathrm{C}, 60 \text { to } 80 \mathrm{~cm} & 1170 \pm 70 \\ \text { HAM-725. } & 0.52 \% \mathrm{C}, 80 \text { to } 100 \mathrm{~cm} & 1160 \pm 80 \\ \text { HAM-726. } & 0.36 \% \text { C, } 100 \text { to } 120 \mathrm{~cm} & 1810 \pm 80 \\ \text { HAM-731. } & 0.14 \% \text { C, } 200 \text { to } 220 \mathrm{~cm} & 3380 \pm 120\end{array}$

Eutrustox (Krasnozem) on plateau, with escarpment up to $8^{\circ}$ slope in Beechmont. Deeply weathered profile on soft weathered Tertiary basalt, covered by subtropical rainforest $\left(28^{\circ} 10^{\prime} \mathrm{S}, 153^{\circ} 12^{\prime} \mathrm{E}\right)$.

HAM-703. $7.92 \% \mathrm{C}, 0$ to $10 \mathrm{~cm}$

HAM-704. $4.53 \% \mathrm{C}, 10$ to $20 \mathrm{~cm}$

HAM-705. $2.88 \% \mathrm{C}, 20$ to $30 \mathrm{~cm}$

HAM-706. $2.01 \%$ C, 30 to $40 \mathrm{~cm}$

HAM-707. $1.15 \% \mathrm{C}, 40$ to $60 \mathrm{~cm}$

HAM-708. $0.85 \% \mathrm{C}, 60$ to $80 \mathrm{~cm}$

HAM-709. $0.75_{\%}^{\sigma} \mathrm{C}, 80$ to $100 \mathrm{~cm}$

HAM-711. $0.58 \% \mathrm{C}, 120$ to $140 \mathrm{~cm}$
$111.0 \pm 1 \%$ modern

$102.2 \pm 1.2 \%$ modern

$$
\begin{array}{r}
240 \pm 60 \\
320 \pm 70 \\
260 \pm 60 \\
1530 \pm 50 \\
2020 \pm 70 \\
2000 \pm 70
\end{array}
$$

Samples of all four profiles coll and subm 1977 by G D Hubble, CSIRO, Cunningham Lab, St Lucia, Queensland. Vertisol dates comply quite well with former Australian Vertisol profile dates from Caniva dist, Victoria (R, v 15, p 258-263), which were interpreted with help of conventional analysis and micromorphology data (Blackburn, Sleeman, \& Scharpenseel, 1979). Dates will be used for soil organic matter decomposition model, which attempts to integrate fast exponential and slower steady-state decomposition phases. Eutrustox (Krasnozem) data are rather young and repeat trends observed in previous Krasnozem dates (BONN664 to -772: R, v 13, p 198-200). Since Oxisols are generally considered to be old soils, either Krasnozem type on basalt weathering is different, or more likely, profiles consist of relatively high members of erosion catenas, standing in erosion equilibrium with much transported younger material as well as with newly formed soil and humus.

\section{REFERENCES}

Blackburn, G, Sleeman, J R, and Scharpenseel, H W, 1979, Radiocarbon measurements and soil micromorphology as guides to the formation of gilgai at Kaniva, Victoria: Australian Jour Soil Research, v 17, p 1-15.

Scharpenseel, H W, 1972, Messung der natürlichen C-14 Konzentration in der organischen Substanz von rezenten Böden, eine Zwischenbilanz: Zeitschr Pflanzenernähr Bodenkunde, v 133, p 241-263.

1977, The search for biologically inert and lithogenic carbon in recent soil organic matter: Soil organic matter studies, Vienna, IAEA, v 2, p 193-200. 
Scharpenseel, $\mathrm{H} \mathrm{W}$ and Neue, $\mathrm{H} \mathrm{U}$, in press, Use of isotopes in studying the dynamics of organic matter in soil, in Internatl conf organic matter in rice soils, Proc: Philippines, IRRI, Los Banos, in press.

Scharpenseel, H W and Pietig, F, 1969, Einfache Boden und Wasserdatierung durch Messung der ${ }^{14} \mathrm{C}$ - und Tritium-Konzentration: Geoderma, v 2, p 273-289.

1971, University of Bonn natural radiocarbon measurements IV: Radiocarbon, v 13, p 189-212.

- 1973, University of Bonn natural radiocarbon measurements VI: Radiocarbon, v 15, p 252-279.

Scharpenseel, H W, Pietig, F, and Schiffmann, H, 1976, Hamburg University radiocarbon dates I: Radiocarbon, v 18, p 268-289.

Scharpenseel, H W and Schiffmann, H, 1977, Hamburg University radiocarbon dates II: Radiocarbon, v 19, p 170-181. 